\title{
Evaluating the Acoustic Effect of Over-the-Rotor Foam-Metal Liner Installed on a Low Speed Fan Using Virtual Rotating Microphone Imaging
}

Daniel L. Sutliff

Glenn Research Center, Cleveland, Ohio

Robert P. Dougherty

OptiNav, Inc., Redmond, Washington

Bruce E. Walker

Channel Islands Acoustics, Camarillo, California 


\section{NASA STI Program . . . in Profile}

Since its founding, NASA has been dedicated to the advancement of aeronautics and space science. The NASA Scientific and Technical Information (STI) program plays a key part in helping NASA maintain this important role.

The NASA STI Program operates under the auspices of the Agency Chief Information Officer. It collects, organizes, provides for archiving, and disseminates NASA's STI. The NASA STI program provides access to the NASA Aeronautics and Space Database and its public interface, the NASA Technical Reports Server, thus providing one of the largest collections of aeronautical and space science STI in the world. Results are published in both non-NASA channels and by NASA in the NASA STI Report Series, which includes the following report types:

- TECHNICAL PUBLICATION. Reports of completed research or a major significant phase of research that present the results of NASA programs and include extensive data or theoretical analysis. Includes compilations of significant scientific and technical data and information deemed to be of continuing reference value. NASA counterpart of peer-reviewed formal professional papers but has less stringent limitations on manuscript length and extent of graphic presentations.

- TECHNICAL MEMORANDUM. Scientific and technical findings that are preliminary or of specialized interest, e.g., quick release reports, working papers, and bibliographies that contain minimal annotation. Does not contain extensive analysis.

- CONTRACTOR REPORT. Scientific and technical findings by NASA-sponsored contractors and grantees.
- CONFERENCE PUBLICATION. Collected papers from scientific and technical conferences, symposia, seminars, or other meetings sponsored or cosponsored by NASA.

- SPECIAL PUBLICATION. Scientific, technical, or historical information from NASA programs, projects, and missions, often concerned with subjects having substantial public interest.

- TECHNICAL TRANSLATION. Englishlanguage translations of foreign scientific and technical material pertinent to NASA's mission.

Specialized services also include creating custom thesauri, building customized databases, organizing and publishing research results.

For more information about the NASA STI program, see the following:

- Access the NASA STI program home page at http://www.sti.nasa.gov

- E-mail your question via the Internet to help@ sti.nasa.gov

- Fax your question to the NASA STI Help Desk at $443-757-5803$

- Telephone the NASA STI Help Desk at 443-757-5802

- Write to: NASA Center for AeroSpace Information (CASI) 7115 Standard Drive Hanover, MD 21076-1320 


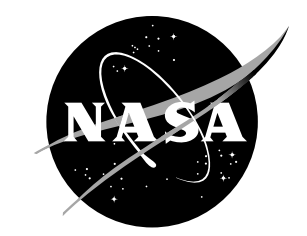

\section{Evaluating the Acoustic Effect of Over-the-Rotor Foam-Metal Liner Installed on a Low Speed Fan Using Virtual Rotating Microphone Imaging}

Daniel L. Sutliff

Glenn Research Center, Cleveland, Ohio

Robert P. Dougherty

OptiNav, Inc., Redmond, Washington

Bruce E. Walker

Channel Islands Acoustics, Camarillo, California

Prepared for the

16th Aeroacoustics Conference cosponsored by the American Institute of Aeronautics and Astronautics and the Confederation of European Aerospace Societies

Stockholm, Sweden, June 7-9, 2010

National Aeronautics and

Space Administration

Glenn Research Center

Cleveland, Ohio 44135 


\section{Acknowledgments}

This work was supported by the Fundamental Aeronautics Subsonic Fixed Wing Program and directly addresses milestone SFW.08.02.042 - Develop Capability for Spectral and Spatial Characterization of Fan In-Duct Broadband Noise. Additionally, results of NRA NNC07CB02C (Improving Phased Array Techniques to Account for Extended Sources of Fan and Jet Noise) were utilized for the research described in this paper. The authors would like to acknowledge the dedicated efforts of the support crew in the Aero-Acoustic Propulsion Laboratory (AAPL).

This work was sponsored by the Fundamental Aeronautics Program at the NASA Glenn Research Center.

Level of Review: This material has been technically reviewed by technical management.

Available from

NASA Center for Aerospace Information 7115 Standard Drive

Hanover, MD 21076-1320
National Technical Information Service 5301 Shawnee Road Alexandria, VA 22312

Available electronically at http://gltrs.grc.nasa.gov 


\title{
Evaluating the Acoustic Effect of Over-the-Rotor Foam-Metal Liner Installed on a Low Speed Fan Using Virtual Rotating Microphone Imaging
}

\author{
Daniel L. Sutliff \\ National Aeronautics and Space Administration \\ Glenn Research Center \\ Cleveland, Ohio 44135 \\ Robert P. Dougherty \\ OptiNav, Inc. \\ Redmond, Washington 98052 \\ Bruce E. Walker \\ Channel Islands Acoustics \\ Camarillo, California 93010
}

\begin{abstract}
An in-duct beamforming technique for imaging rotating broadband fan sources has been used to evaluate the acoustic characteristics of a Foam-Metal Liner installed over-the-rotor of a low-speed fan. The NASA Glenn Research Center's Advanced Noise Control Fan was used as a test bed. A duct wallmounted phased array consisting of several rings of microphones was employed. The data are mathematically re-sampled in the fan rotating reference frame and subsequently used in a conventional beamforming technique. The steering vectors for the beamforming technique are derived from annular duct modes, so that effects of reflections from the duct walls are reduced.
\end{abstract}

\section{Nomenclature}

AAPL Aero-Acoustic Propulsion Laboratory

ANCF Advanced Noise Control Fan

BPF Blade Passing Frequency

FML Foam-Metal Liner

OTR Over the Rotor

PWL Acoustic Sound Power Level

SPL Acoustic Sound Pressure Level

VRM Virtual Rotating Microphone

\section{Introduction}

Significant reduction in aircraft noise is required to meet stricter noise regulation in the USA and Europe. Any overall reduction in aircraft noise must include engine noise reduction since the turbofan engine is a large contributor to aircraft noise. In order to effectively achieve noise reduction, detailed understanding of the physics of noise generation (Ref. 1) is required. The NASA focus area funding this work-Fundamental Aeronautics, Subsonic: Fixed Wing Program - emphasizes developing technologies for diagnostics of noise for subsonic aircraft. 
In an earlier effort (Ref. 2), a Foam-Metal Liner was developed for and tested on a low speed fan to attenuate the fan noise. This type of liner represents a significant advance over traditional liners due to the possibility for placement in close proximity to the rotor. An advantage of placing treatment in this region is that the acoustic near field is modified, thereby inhibiting noise generation mechanisms. This can result in higher attenuation levels than can be achieved by liners located in the nacelle inlet. In addition, foammetal liners could potentially replace the fan rub-strip and containment components, ultimately reducing engine components and thus weight, which can result in a systematic improvement. Foam-metal liners have the potential to reduce fan noise by $4-\mathrm{dB}$ overall based on this earlier study, but questions remained as to the physics of the noise attenuation mechanism.

To provide some insight into the physics of the fan noise attenuation achieved by the FML, an in-duct beamforming technique designed to separate rotating broadband sources from the total noise inside the fan duct was developed and used to acoustically image the fan. This technique, designated the Virtual Rotating Microphone, is based on the re-sampling of the data into the rotating reference frame. The NASA Glenn Research Center's Advanced Noise Control Fan was used as the test bed. Several configurations of the fan casing area were tested to explore the capability of the VRM in providing physical insights. The VRM technique is in its infancy and hence any conclusions drawn from this technique should be considered tentative.

\section{Test Setup and Conditions}

The test bed was the Advanced Noise Control Fan (Refs. 3 and 4); a 4-ft diameter low speed fan used for validation of noise reduction concepts. The ANCF is a highly configurable, ducted fan rig located in the Aero-Acoustic Propulsion Laboratory (Ref. 5) (Fig. 1). The ANCF, shown in Figure 2, operates inside an enclosed, compact farfield arena designed such that the ANCF is in an anechoic environment within the AAPL. The AAPL is a hemispherical anechoic (to $125 \mathrm{~Hz}$ ) test facility that allows for farfield noise measurements. The nominal operating condition of the ANCF is $1800 \mathrm{rpm}$ (375 ft/sec tip speed) providing an inlet duct Mach number of $\sim 0.15$. The 16-bladed fan generates a fundamental blade passing frequency of $\sim 500 \mathrm{~Hz}$. The ANCF is comprised of a series of 11 or $12 \mathrm{in.} \mathrm{long} \mathrm{cylindrical} \mathrm{spools} \mathrm{that} \mathrm{are}$ axially interchangeable, enabling rapid testing of a variety of configurations. The ANCF has the ability to run rotor-alone (no stator or inlet guide vanes are required for support). All configurations described in this paper were tested in the rotor-alone configuration.

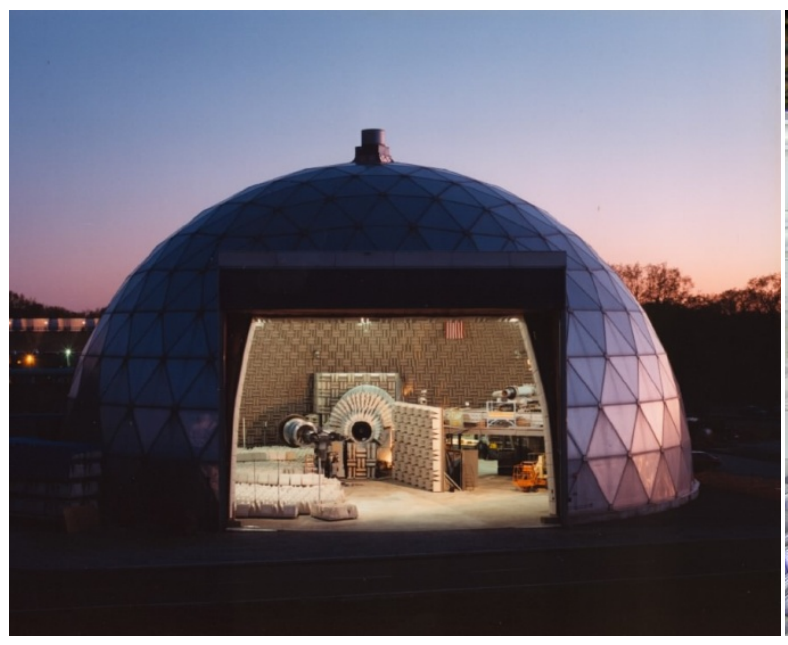

Figure 1.-Aero-Acoustic Propulsion Laboratory.

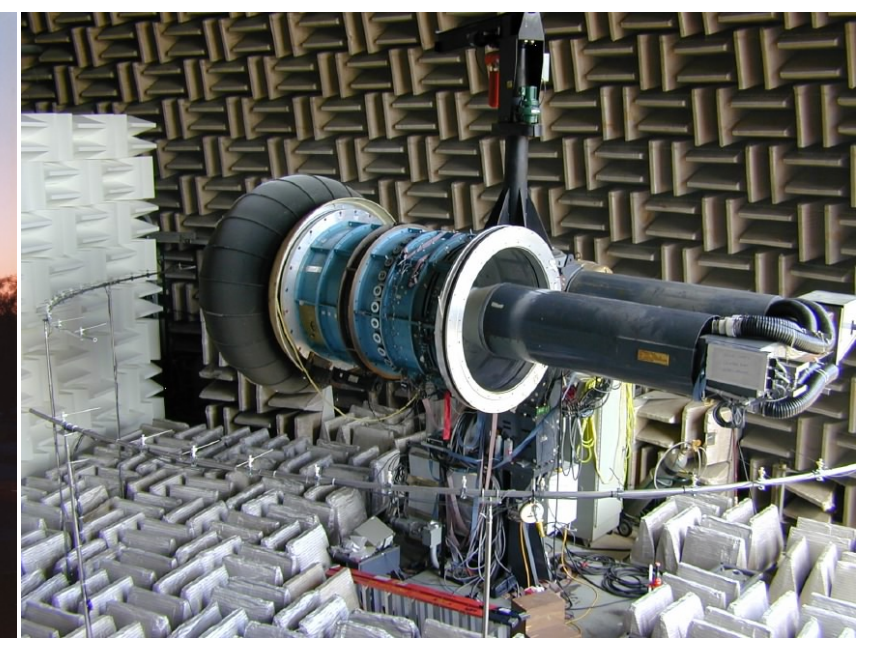

Figure 2.-Advanced noise control fan. 
The FML, which was from the earlier study (Ref. 2), was a 9 in. long axial liner, with a depth of 2 in., integrated into a 12 in. spool piece. Figure 3 shows the integrated liner spool piece prior to the fan build-up. The foam-metal open cell characteristics were 80 ppi and 8 percent density. The acoustic performance of the liner was significant, when installed Over-the-Rotor achieving up to $4 \mathrm{~dB}$ of overall broadband attenuation. One effect of the foam-metal liner on the flow was notable: it reduced the unsteady wall pressures near the blade tip, perhaps due to modification of the blade tip leakage flow. This may have contributed to the noise reduction achieved by the installation of the FML/OTR.

To better understand the physics of the attenuation mechanism the in-duct array was used on several configurations. A baseline configuration with the fan blades over the standard ANCF rub-strip was also acquired (Fig. 4). In this configuration, the tip clearance is very small $\left(1 / 64^{\text {th }} \mathrm{in}\right.$.) as the rub-strip is "fitted" to the fan by allowing the fan to rub-in during the initial installation. An additional baseline was acquired with the FML spool piece situated in the OTR location, but with the surface of the liner taped over to provide a hardwall case (Fig. 5). Note that because of concerns about the blades rubbing on a "metal" surface, the tip gap in this configuration is larger $\left(5 / 64^{\text {th }}\right.$ in.) than the standard rub-strip $\left(1 / 64^{\text {th }}\right.$ in.). The primary configuration to determine the effects of the FML was with the liner fully exposed (Fig. 6). To help localize the effect the liner was partially taped to expose either the forward or aft half of the liner (Fig. 7). Data were acquired in several other configurations but are not reported herein (Table I).

Additional fully-taped and fully-exposed configurations were run with a 6 or 12 in. rod installed upstream of the fan to create a strong wake which when ingested by the fan is expected to generate a strong stationary acoustic source. This provided a method to compare results from using the VRM to standard stationary reference frame beamforming. The configurations are listed in Table I.

Finally to provide a sanity check on the beamforming results, farfield data were acquired at all configurations. The farfield data were processed as discussed in References 3 and 5 to obtain the broadband directivity characteristics.

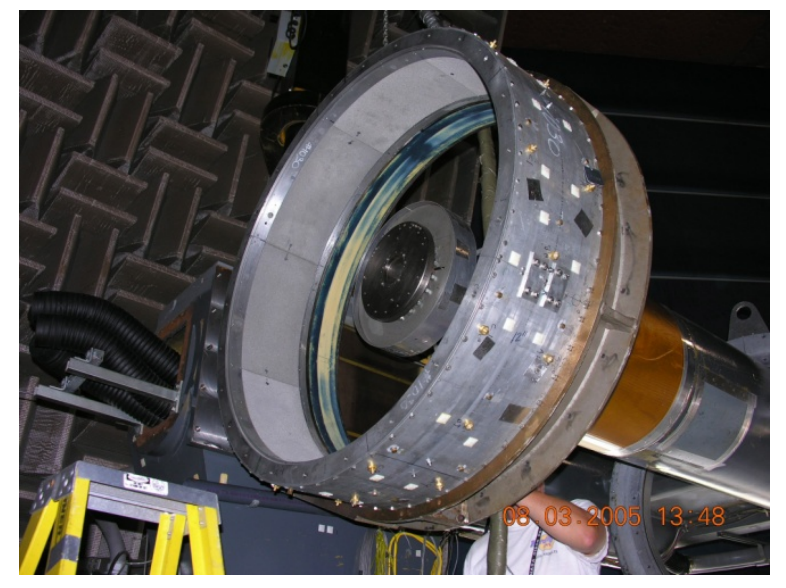

Figure 3.-FML spool piece.
TABLE I.-CONFIGURATIONS TESTED (Reported configurations in bold)

\begin{tabular}{|c|l|}
\hline $\begin{array}{c}\text { CONFIG } \\
\text { ID }\end{array}$ & DESCRIPTION \\
\hline I & Baseline (1/64" tip gap) \\
\hline II & OTR/FML taped (5/64" tip gap) \\
\hline III & OTR/FML taped 6" rod in inlet \\
\hline IV & OTR/FML taped 12" rod in inlet \\
\hline V & OTR/FML exposed \\
\hline VI & OTR/FML exposed 6" rod in inlet \\
\hline VII & OTR/FML exposed 12" rod in inlet \\
\hline VIII & OTR/FML forward 1/2 portion exposed \\
\hline IX & OTR/FML aft 1/2 portion exposed \\
\hline
\end{tabular}




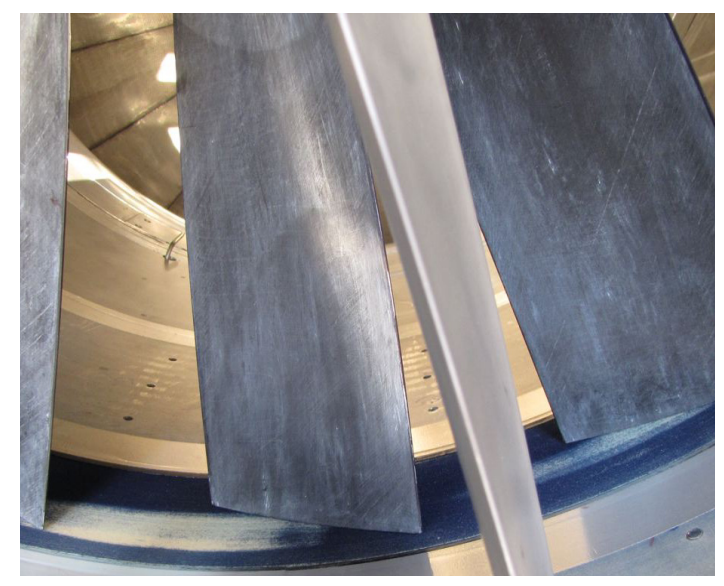

Figure 4.-Standard rub-strip showing small tip gap provides alternate hardwall baseline (stator vane not present during testing).

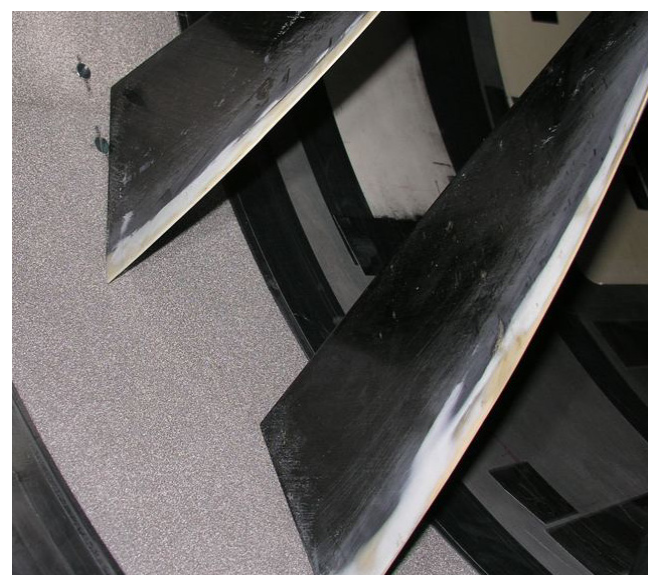

Figure 6.-Fully exposed FML/OTR.

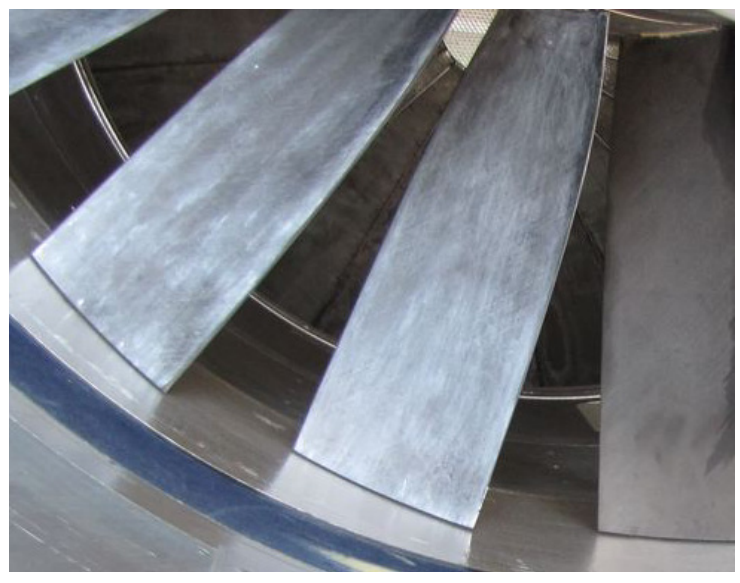

Figure 5.-Rub-strip replaced with FML/OTR showing larger tip gap. FML is taped to provide hardwall baseline.

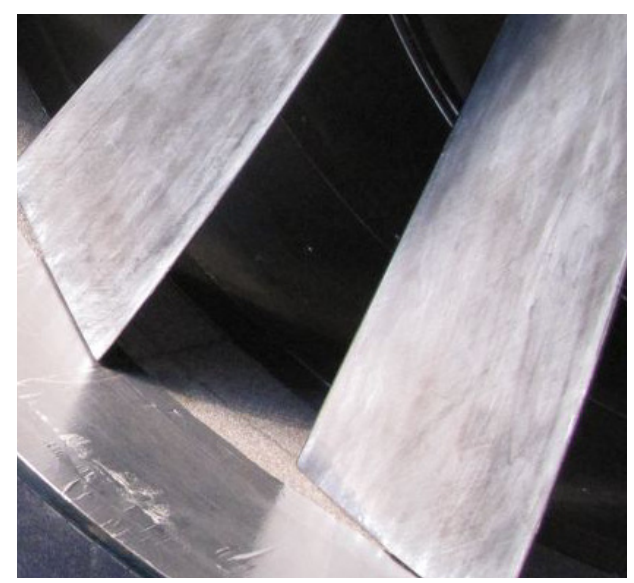

Figure 7.-Partially exposed FML/OTR. 


\section{In-Duct Beamforming}

A companion paper presents (Ref. 6) the detailed evaluation of the in-duct beamforming technique (Ref. 7) for imaging rotating broadband fan sources. Briefly, a phased array consisting of several rings of microphones plus an axial array was employed (Fig. 8). Each circumferential ring had 30 equally spaced microphones. The inlet axial array had 14 microphones. Microphones 9, 11, and 13 from the axial array are also located in a circumferential ring. The axial array microphones are spaced $1.5 \mathrm{in}$. apart. The data are mathematically re-sampled to a frame of reference rotating with the fan and subsequently used in a conventional beamforming technique (Refs. 8 and 9) in the rotating frame. The steering vectors for the beamforming are derived from annular duct modes, so that effects of reflections from the duct walls are reduced. In contrast with other work, the steering vectors represent the effect of the unsteady pressure at the fan, rather than the Green's function. This improves the condition of the formulation and provides a connection to analytical studies. The test included a condition in which two of the fan blades were altered to create noise sources at known locations. Referring to Figure 8, the VRM images were obtained using the $\mathrm{A}, \mathrm{B}$, and $\mathrm{C}$ circumferential arrays; the computed in-duct PWLs were obtained using modal beamforming from rows $\mathrm{A}$ and $\mathrm{C}$ combined with the axial array.

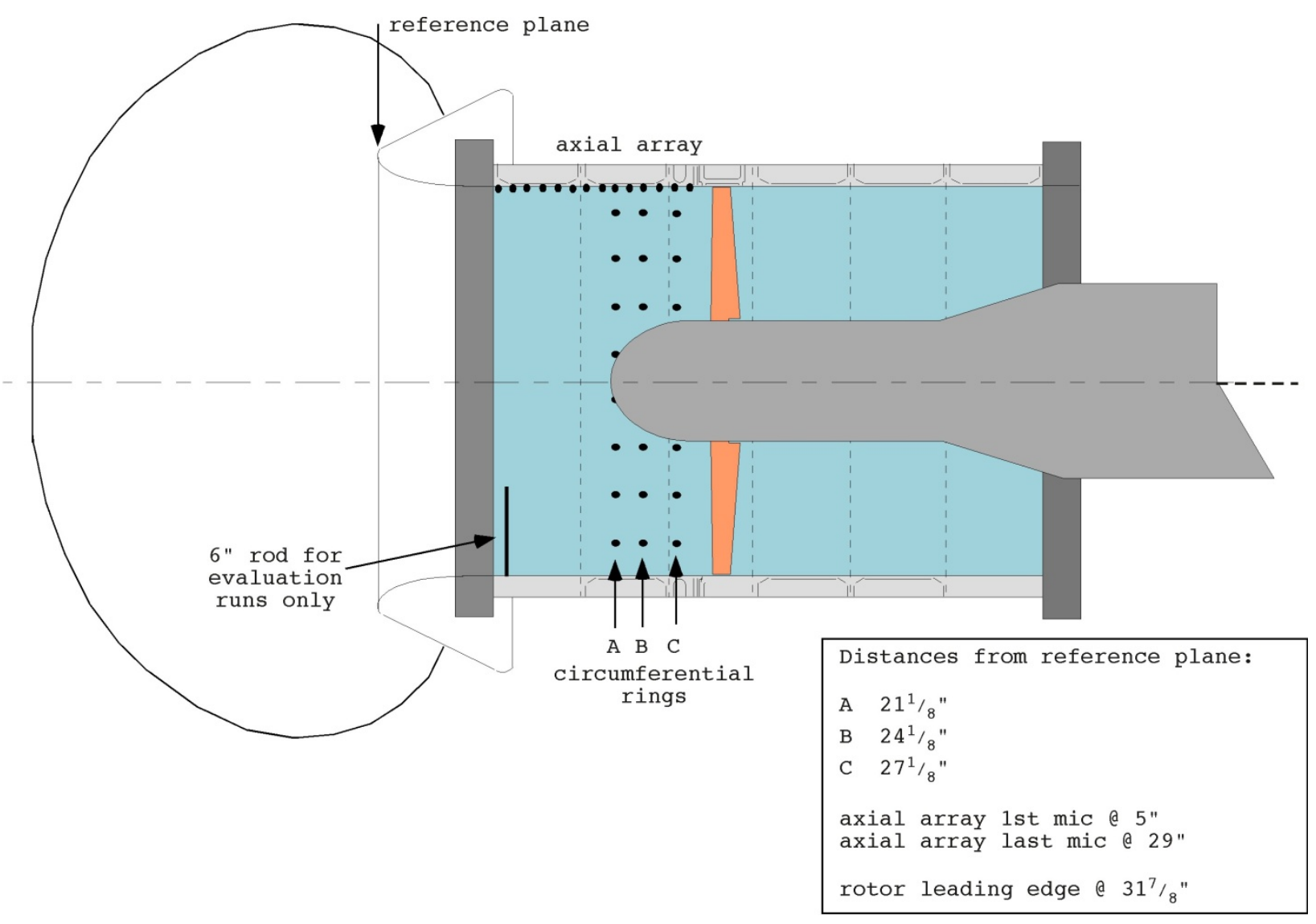

Figure 8.-Microphone array locations in ANCF. 


\section{Results}

All of the results in this section are broadband, i.e., the fan tones were removed from the data before processing. All data were acquired with no stator vanes installed. To evaluate the VRM separation technique a few runs were acquired with a rod installed in the inlet at bottom dead center (BDC) of the duct. The remainder of the images were acquired with a clean inlet duct.

\section{Evaluation of VRM Separation Technique}

Figure 9 shows the comparison between data from the inlet array processed using the time series data (a) acquired in the stationary reference plane, as one might do in conventional phased array processing, or (b) after the time-series have been re-sampled into the rotating reference frame using the VRM process. The $1^{\text {st }}$ three harmonics are imaged. The center frequency of the band is displayed on the upper left of the images, the beamform map peak SPL on the upper right. In the stationary frame, the "hotspot" from the rod wake interacting with the fan is clearly seen near the bottom of the duct (the rod was located BDC). With VRM processing the "hotspot" is not seen since the technique removes stationary sources. The total signal is greater than that of the rotating component for all harmonics (e.g., $\sim 90 \mathrm{vs.} 76 \mathrm{~dB}$ at BPF). The stationary signal peak drops across the harmonics while the rotating levels are constant across the three harmonics. Qualitatively, this difference was expected and confirms that the VRM technique is indeed picking out a component of the total acoustic signal. (This is based on the assumption that the total signal = stationary + rotating signals.)

\section{VRM Image Analysis of FML}

Figures 10 and 11 show the results using the VRM technique on three configurations (I) with the fan over the baseline rub-strip with tight clearance, (II) the fan over the FML taped - a more open tip clearance, and (V) the fan over the exposed FML. Figure 10 corresponds to fan harmonics that can be compared to the farfield data acquired. Figure 11 corresponds to fan harmonics above the available farfield data. The imaged noise generated by the fan over the tight clearance rub-strip is the loudest, followed by the taped FML. (A unique feature of this low-speed, ultra-lightly loaded fan is that the fan noise increases with decreasing tip gap.) The exposed FML yields the lowest levels. For the hardwall, tight rub strip case, particularly at the mid-range frequencies, the image shows the source of the noise is weighted toward the blade tip. This may be the influence of the noise generated by the tip leakage. For the cases with the tip gap opened, the image shows a more uniform noise source distribution. This may indicate that the tip leakage strength is reduced, resulting in a uniform acoustic radiation from the blade. The presence of the FML reduces the radiation uniformly across the blade, indicating that the FML affects the entire source distribution along the fan blade.

One effect of phased array processing is that images are typically presented with a floating scale to provide better resolution over the dynamic range. Sometimes this scaling can hide differences between configurations. It can be instructive to compare cases on a fixed scale. Figure 12 shows the results with all three cases imaged with a fixed level of $82 \mathrm{~dB}$ max while keeping the $15 \mathrm{~dB}$ range. The differences between the configurations are starker.

\section{Spectral Analysis of VRM}

Typically, image processing entails computing the beamform map levels, which are then plotted along with the spectra at a particular frequency. (This works better in presentations when the frequency can be advanced.) The spectral content for each of the three configurations along with an image slice at 3BPF is shown in Figure 13. The spectra confirm the relative acoustic levels between the three configurations. Note that the spectral shape of the hardwall with rub-strip (tight tip clearance) configuration shows a peak at $\sim 1500 \mathrm{~Hz}$, whereas the configurations with the open tip gap do not show a peak, but the general fall off in level with increasing frequency. The slope of the fall off is modified with the exposure of the FML creating a more rapid fall-off with respect to the taped configuration. The spectral character of the exposed FML configuration relative to the taped shows a relatively consistent reduction in SPL versus frequency. This may be more evidence that the OTR/FML reduces the acoustic sources along the entire span of the blade. 


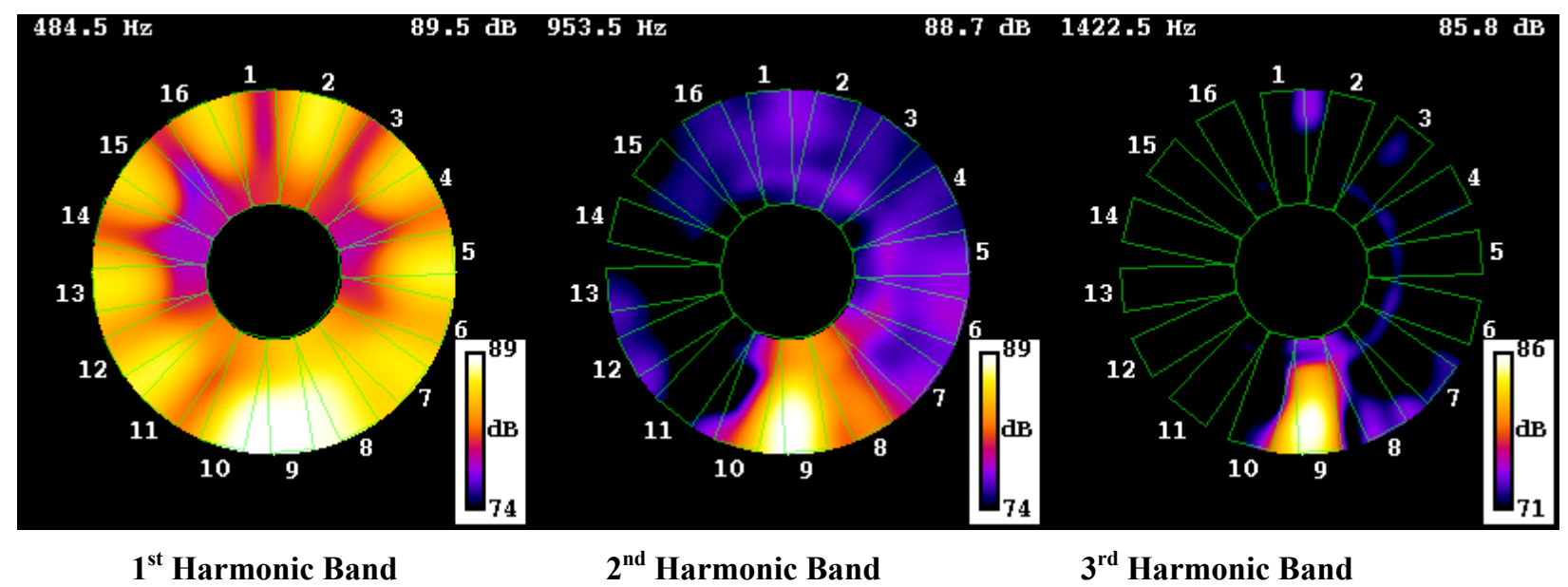

(a) Stationary Frame

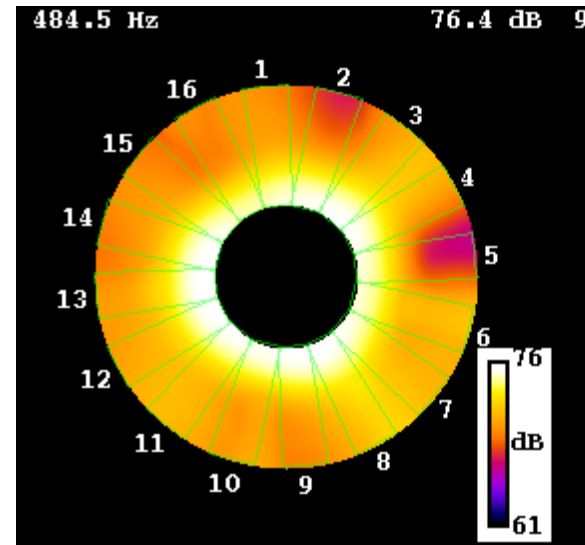

$1^{\text {st }}$ Harmonic Band

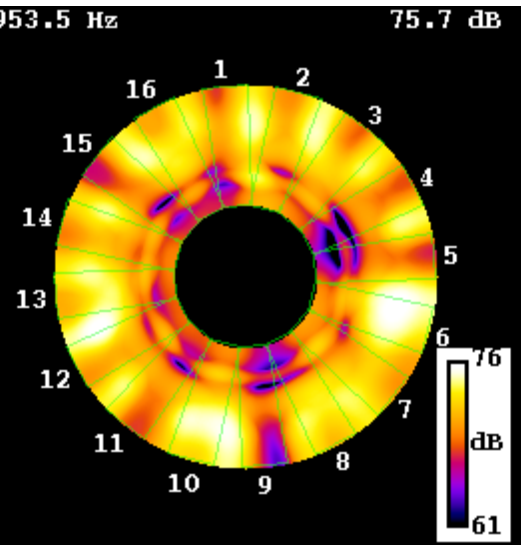

$2^{\text {nd }}$ Harmonic Band
$1422.5 \mathrm{~Hz}$

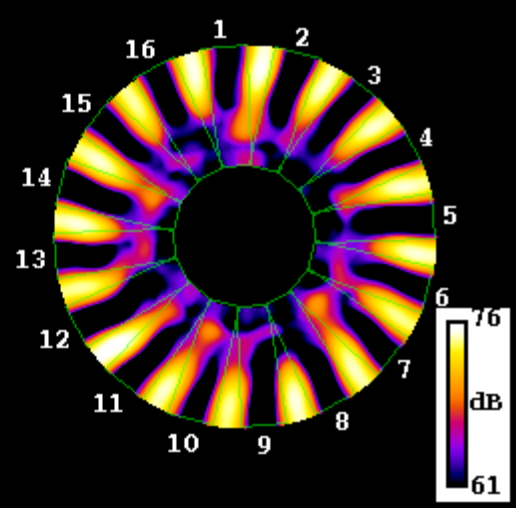

$3^{\text {rd }}$ Harmonic Band

(b) VRM Frame

Figure 9.-Comparison of in-duct stationary to virtual rotating microphone beamforming results with 6 in. rod installed in the inlet at bottom dead center. 

(I) Hardwall-Rub-strip
$\left(1 / 64^{\text {th }}\right.$ tip gap)
(II) Hardwall-taped FML
$\left(5 / 64^{\text {th }}\right.$ tip gap)
(V) Exposed FML
$\left(5 / 64^{\text {th }}\right.$ tip gap)

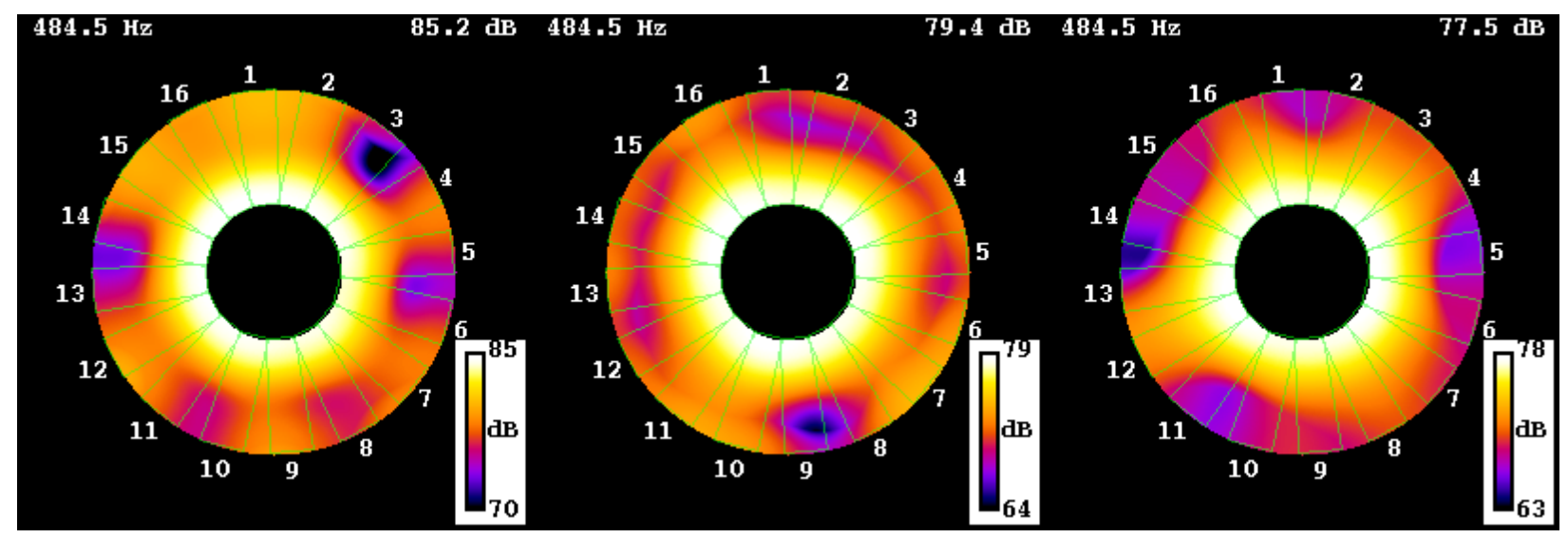

(a) $1^{\text {st }}$ Harmonic Band

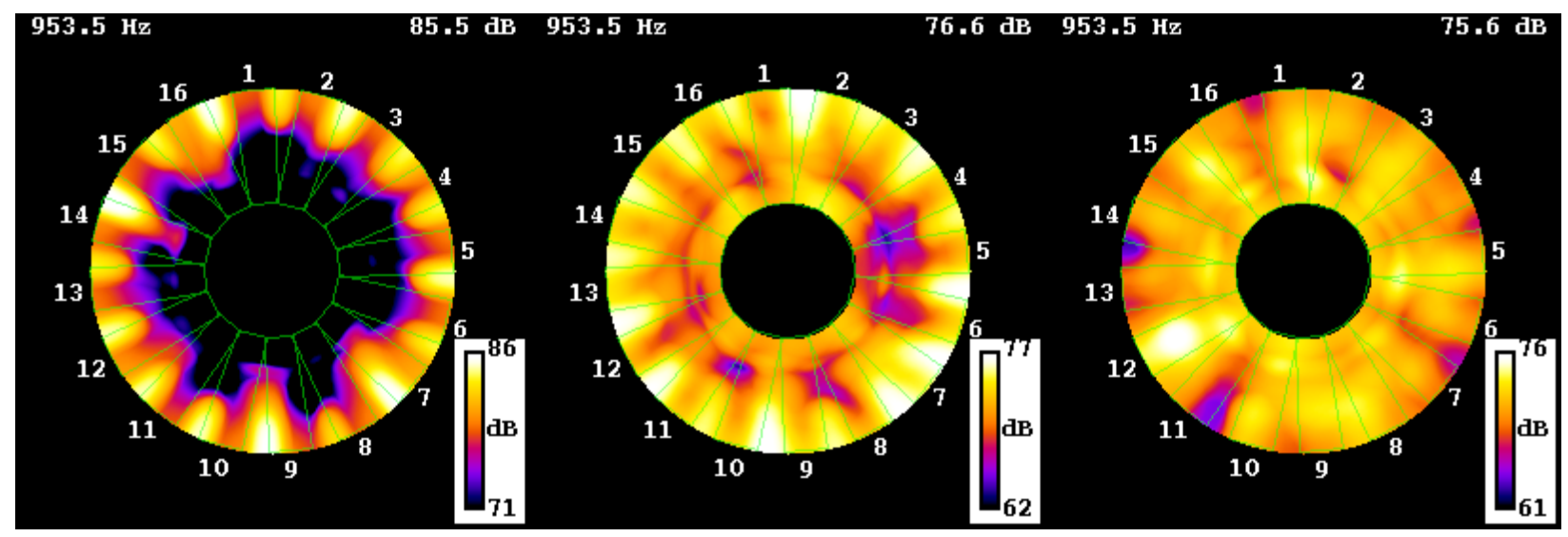

(b) $2^{\text {nd }}$ Harmonic Band

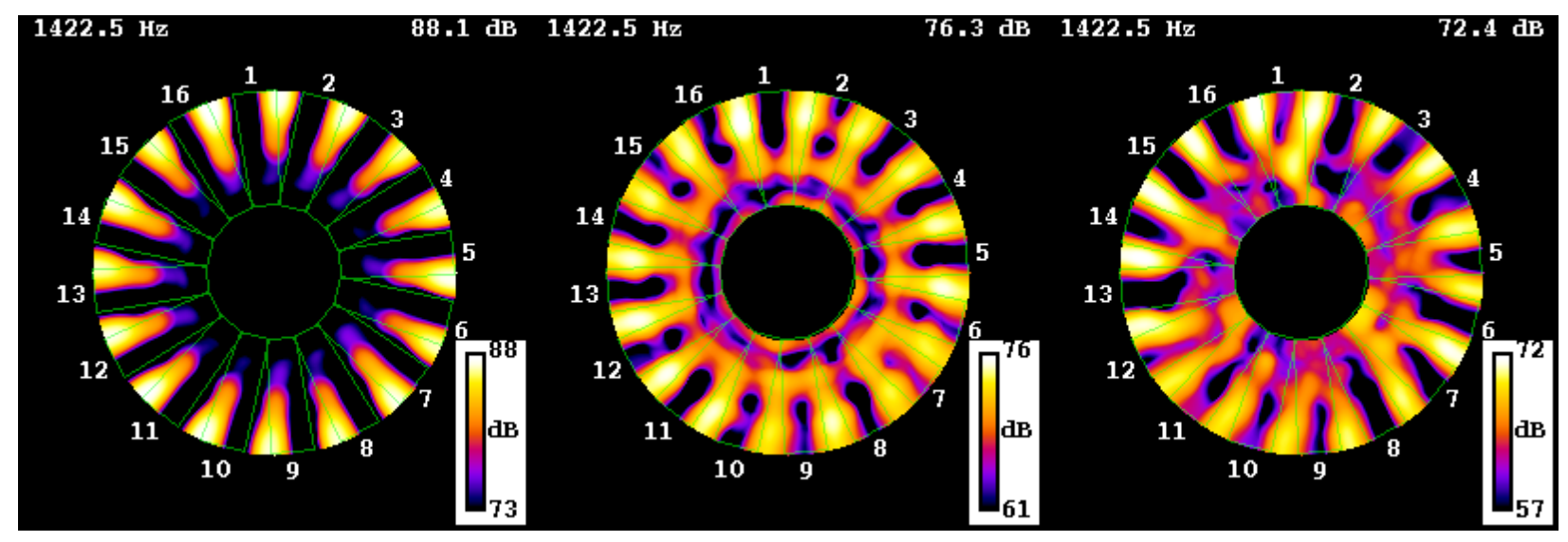

(c) $3^{\text {rd }}$ Harmonic Band

Figure 10.-In-duct virtual rotating microphone beamforming results with clean inlet (for $1^{\text {st }}$ three harmonicscorresponding to farfield data acquired). 

(I) Hardwall-Rub-strip
$\left(1 / 64^{\text {th }}\right.$ tip gap)
(II) Hardwall-taped FML
(V) Exposed FML
$\left(5 / 64^{\text {th }}\right.$ tip gap)
$\left(\mathbf{5} / \mathbf{6} 4^{\text {th }}\right.$ tip gap)

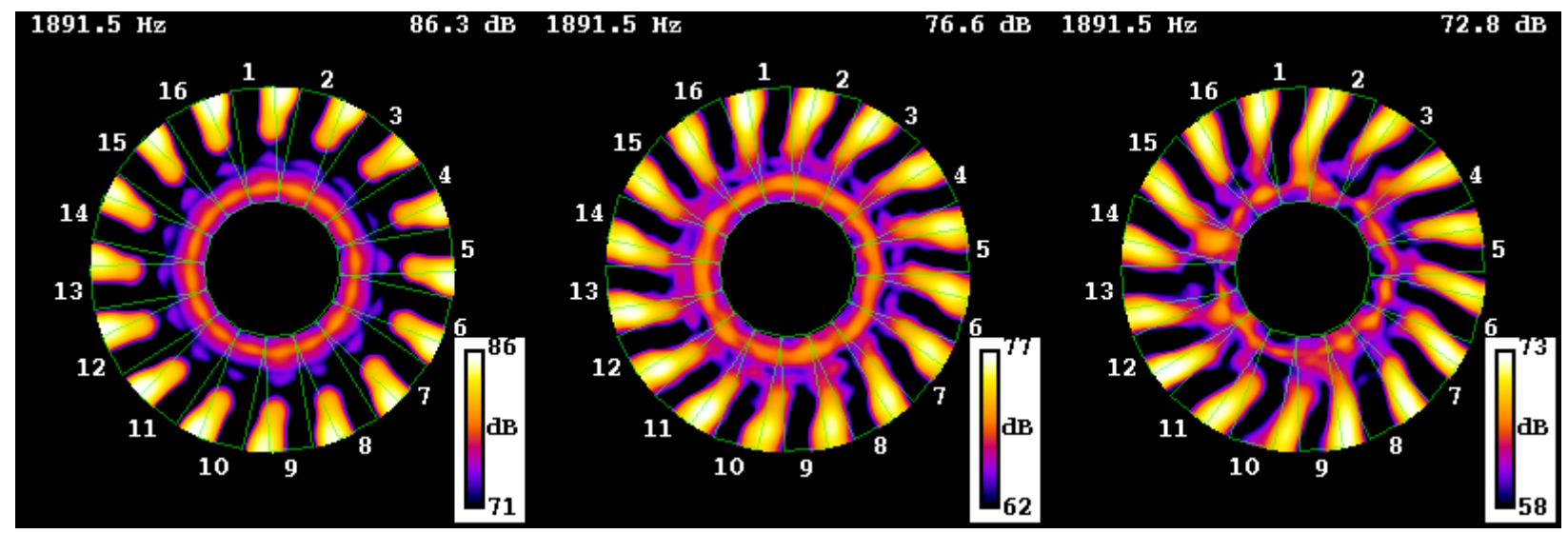

(a) $4^{\text {th }}$ Harmonic Band

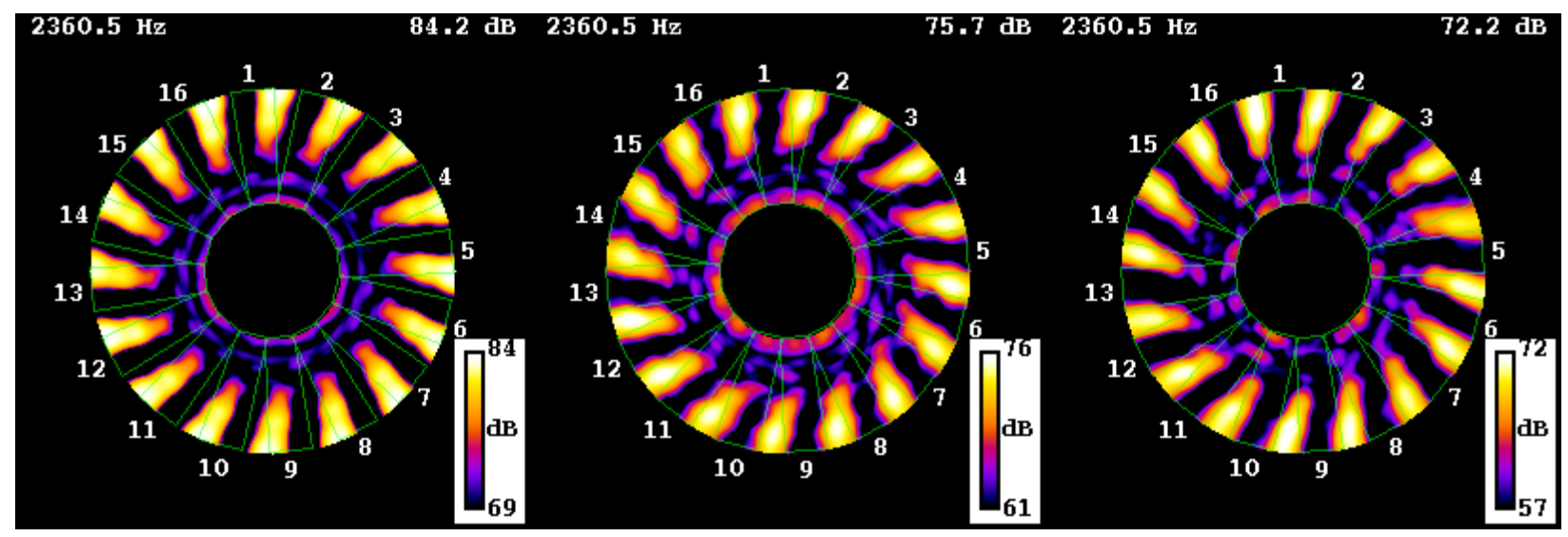

(b) $5^{\text {th }}$ Harmonic Band

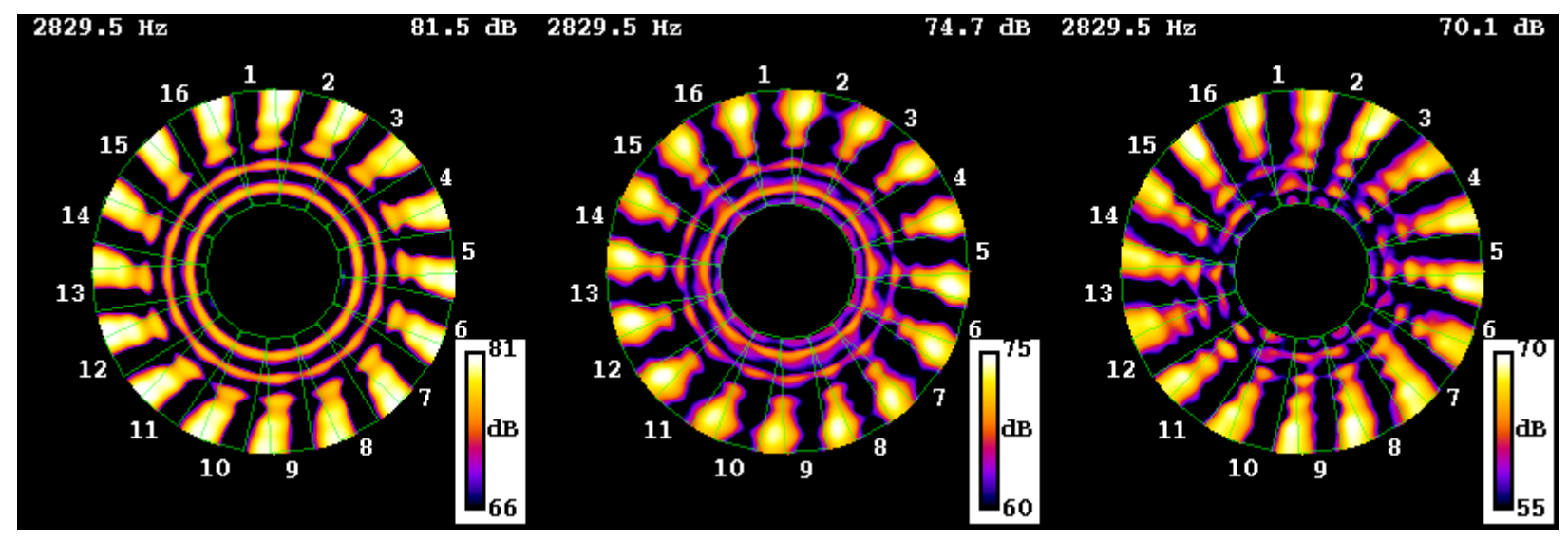

(c) $6^{\text {th }}$ Harmonic Band

Figure 11.-In-duct virtual rotating microphone beamforming results with clean inlet (for higher harmonics-above farfield data acquired). 

(I) Hardwall-Rub-strip
(II) Hardwall-taped FML
(V) Exposed FML
$\left(1 / 64^{\text {th }}\right.$ tip gap)
$\left(\mathbf{5} / \mathbf{6 4 ^ { \text { th } }}\right.$ tip gap)
$\left(5 / 64^{\text {th }}\right.$ tip gap)

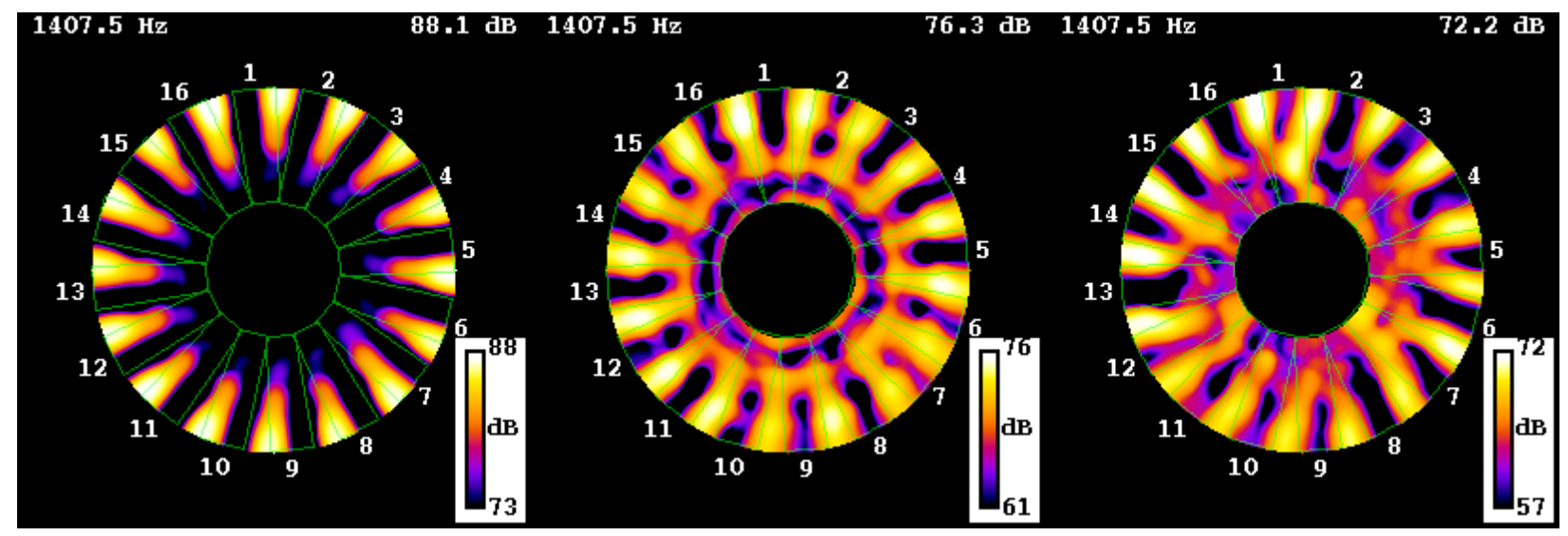

(a) Floating Scale

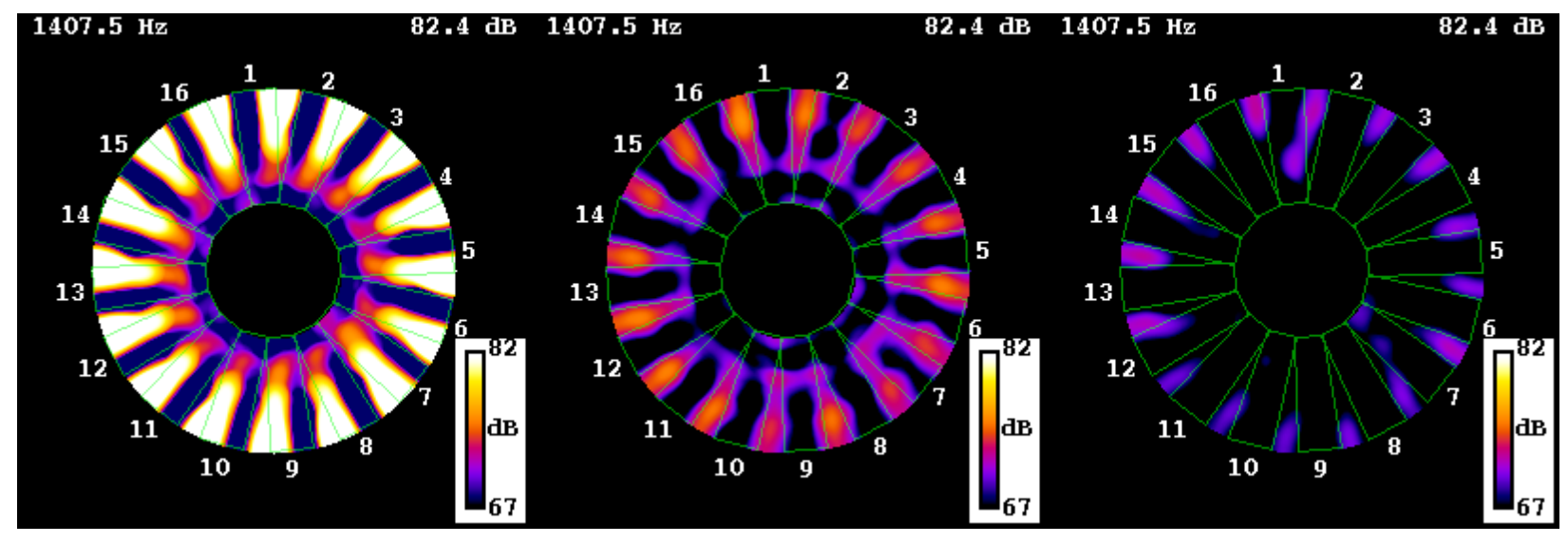

(b) Fixed Scale

Figure 12.-In-duct virtual rotating microphone beamforming results (comparing floating to fixed scale) ( $3^{\text {rd }}$ harmonic chosen for illustration). 

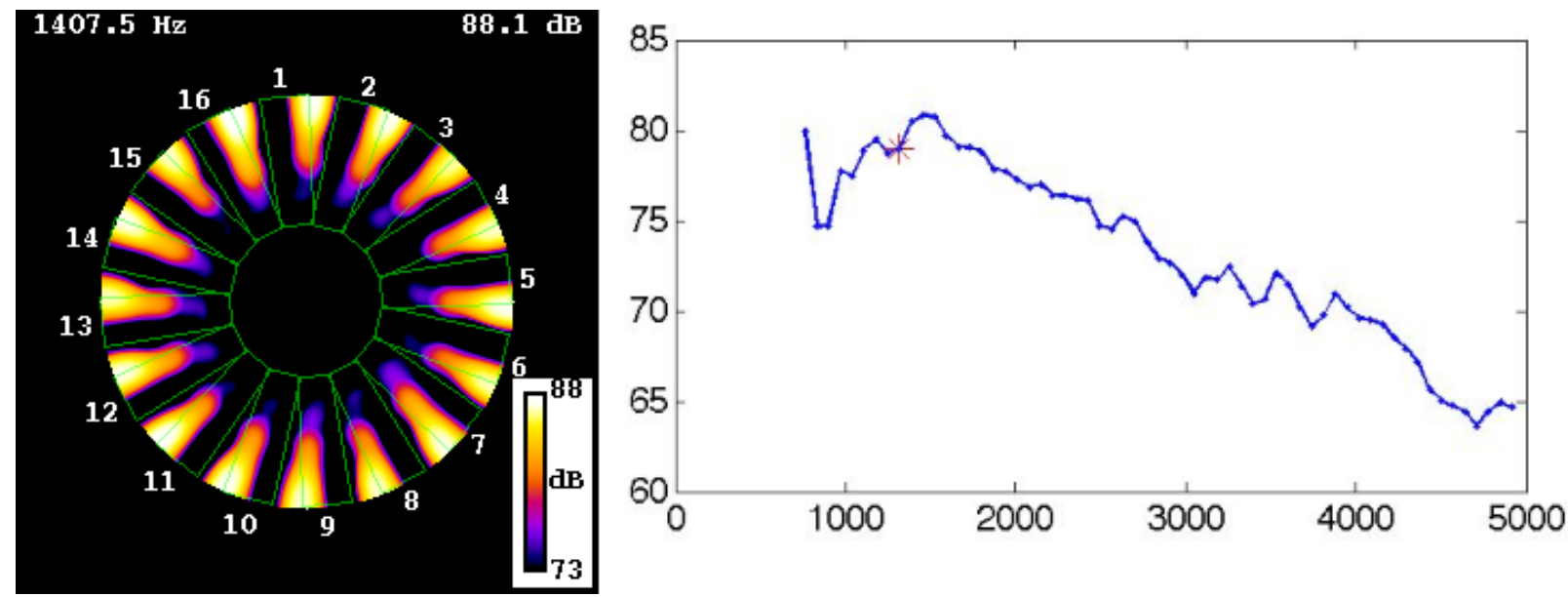

(a) Hardwall: rub-strip (1/64 ${ }^{\text {th }}$ tip gap).
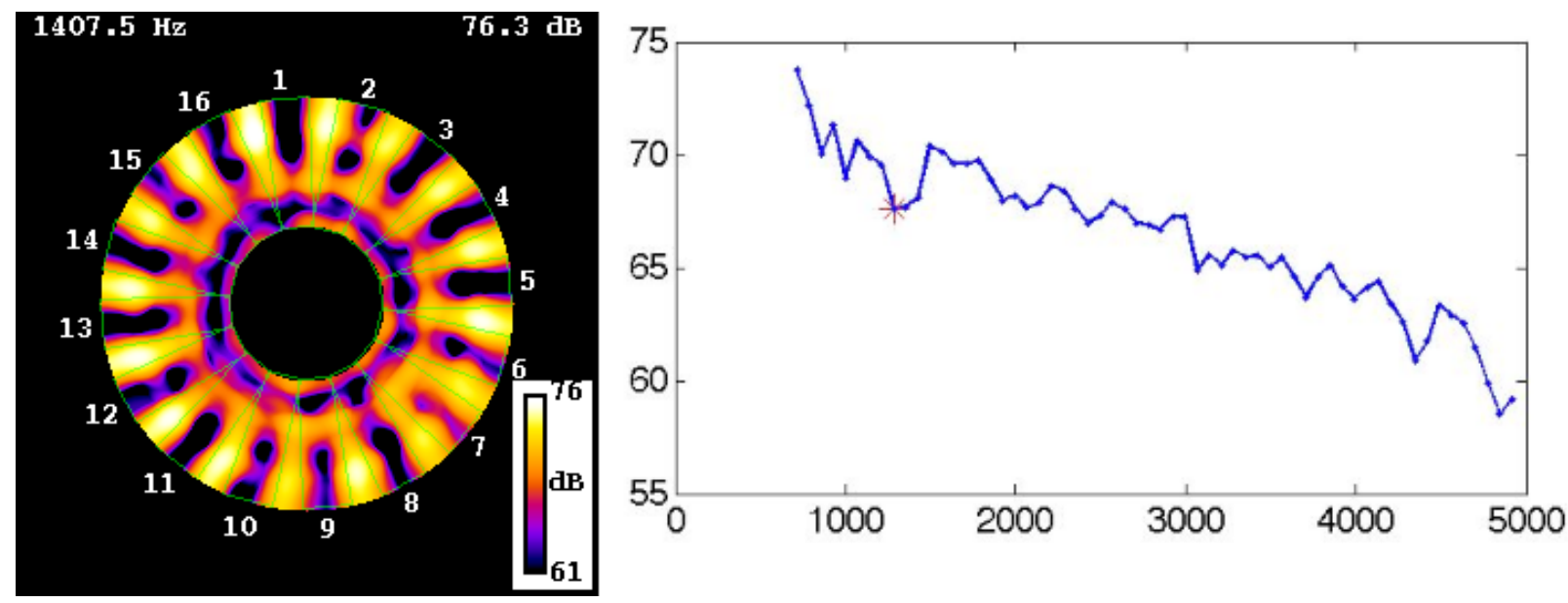

(b) Hardwall: FML taped $\left(5 / 64^{\text {th }}\right.$ tip gap).
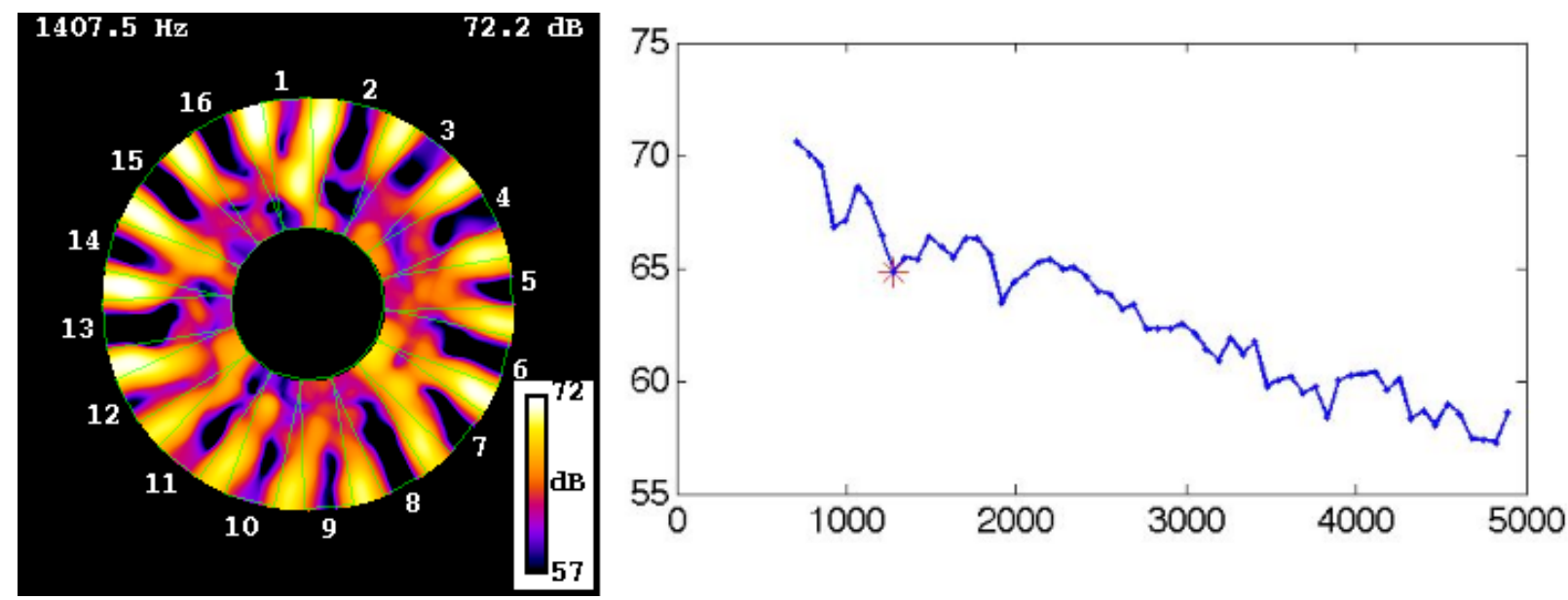

(c) Exposed FML (5/64 ${ }^{\text {th }}$ tip gap).

Figure 13.-In-duct virtual rotating microphone beamforming results with spectral slice. 


\section{Farfield Substantiation}

Farfield data were acquired and processed to analyze the broadband content around the first three fan harmonics of the three configurations (I) with the fan over the baseline rub-strip with tight clearance, (II) the fan over the FML taped - a more open tip clearance, and (V) the fan over the exposed FML. Reference 3 describes the technique for computing broadband levels in detail and Reference 5 presents in-depth farfield acoustic results from these configurations. Figure 14 shows the farfield broadband directivity. Figure 15 compares the inlet-sector PWL, geometrically integrated from the farfield directivity, to that computed by the in-duct beamforming processing technique computed from modal beamforming.

The trends between the two methods for computing PWL agree. The rub-strip configuration is the loudest, followed by the taped FML, with the exposed FML the quietest. The increase in effectiveness of the FML at the higher harmonic bands is confirmed, just as shown by the VRM. However, the farfield acoustic results have some additional noise sources. The $1^{\text {st }}$ is a known increase in SPL in the lower frequency range of the $1^{\text {st }}$ harmonic band from the close proximity of a treated wall in front of the ANCF. (This was a necessary design compromise during construction of the local anechoic region (Ref. 10)). This causes a uniform increase in turbulence ingested by the rotor that could cause increased noise in the stationary frame that the VRM technique does not measure by design. In addition, there may be some spillover from the exhaust noise into the forward arc measurement zone. This would have the most effect in the FML configurations as the strong peak at $40^{\circ}$ does not dominate the inlet-sector PWL computation and are the cases where the in-duct and far field results show greater differences (e.g., the exposed FML configuration). Another possibility is that the array being close to the rotor tip over emphasizes changes in that area. These effects could account for most of the differences.

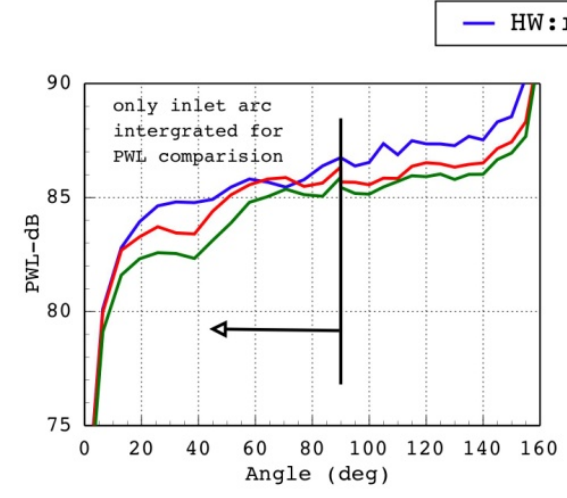

(a) 1st Harmonic Band

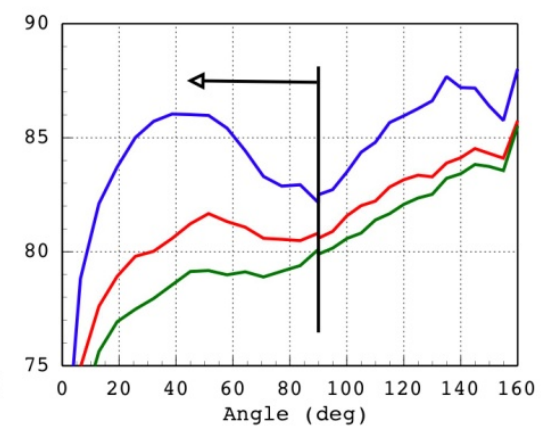

(b) 2nd Harmonic Band

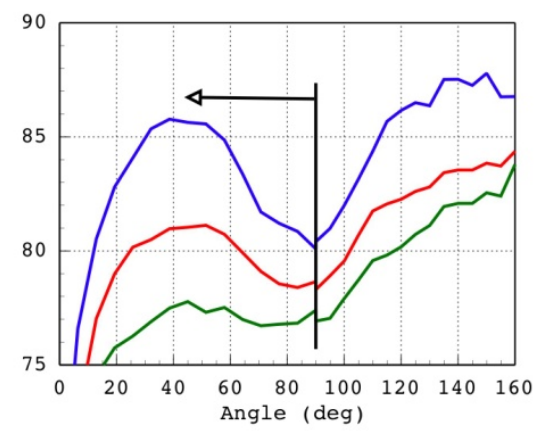

(c) 3rd Harmonic Band

Figure 14.-Farfield directivity of various configurations.

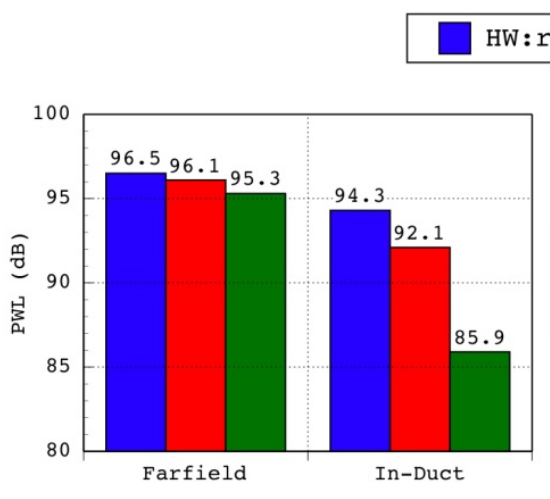

(a) 1st Harmonic Band

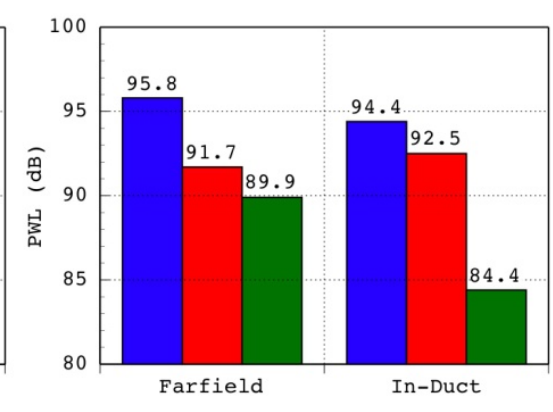

(b) 2nd Harmonic Band
FML exposed

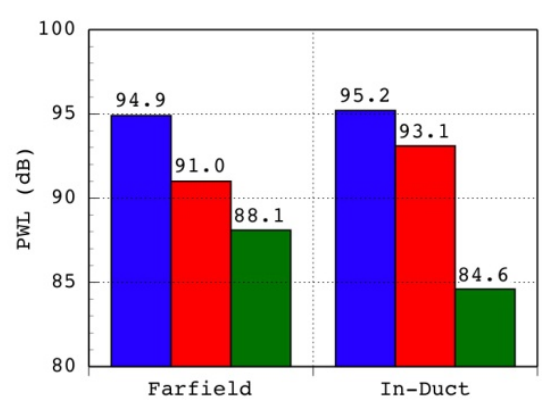

(c) 3rd Harmonic Band

Figure 15.--Integrated PWL for various configurations. 


\section{Conclusions}

A duct wall mounted beamforming array using a Virtual Rotating Microphone technique to detect and localize rotating sources inside the reflective in-duct environment was successfully used to evaluate the characteristics of a Foam-Metal Liner installed Over-the-Rotor of a low-speed fan. Acoustic images of the fan blades were obtained. The VRM technique separated the rotating acoustic signals from the total acoustic signal. The technique also correctly computed the farfield PWL trends and measured the quantitative differences between several configurations. The VRM showed that the noises sources were weighted toward the tip with the tight rub-strip clearance when comparing to a more open tip clearance. The VRM showed that noise source distribution along the blade was reduced uniformly as a result of the FML. These speculations as to how the VRM phased array technique elucidated the physics of the acoustic sources are tentative, but show promise. The VRM technique should continue to be refined to increase the resolution in order to better ascertain the physics of the sources. A useful feature would be to

incorporate region-of-interest screening to further geometrically quantify the spectral characteristics of induct sources.

\section{References}

1. Aeroacoustics of Flight Vehicles: Theory and Practice - Volume 2: Noise Control, NASA RP-1258, Edited by H.H. Hubbard, August, 1991.

2. Sutliff, D.L., and Jones, M.G., "Foam-Metal Liner Attenuation of Low-Speed Fan Noise," AIAA-2008-2097.

3. Loew, R.A., Lauer, J.T., MCAllister, J., and Sutliff, D.L., "The Advanced Noise Control Fan," NASA/TM-2006-214368, also AIAA-2006-3150.

4. McAllister, J., Loew, R.A., Lauer, J.T., and Sutliff, D.L., "The Advanced Noise Control Fan Baseline Measurements," AIAA-2009-624-779.

5. Cooper, B.A., "A Large Hemi-Anechoic Chamber Enclosure for Community-Compatible Aeroacoustic Testing of Aircraft Propulsion Systems," Journal of the Institute of Noise Control Engineering of the USA, Jan/Feb 1994.

6. Dougherty, R.P., Walker, B.E., and Sutliff, D.L., "Locating Broadband Sources on a Low Speed Fan Using Virtual Rotating Microphone Imaging," AIAA-2010-3736.

7. Dougherty, R.P., Walker, B.E., "Virtual Rotating Microphone Imaging of Broadband Fan Noise," AIAA-2009-3121.

8. Dougherty, R.P., "Beamforming in Acoustic Testing," Chapter 2 in Aeroacoustic Testing, T.J. Mueller, ed., Springer-Verlag, 2002.

9. Dougherty, R.P., Mendoza, J.M., "Nacelle In-Duct Beamforming Using Modal Steering Vectors," AIAA-2008-2812.

10. Sutliff, D.L., "Acoustic Characteristics of the Active Noise Control Fan Located in the Compact Farfield Arena," Technical Progress Report, Contract NAS3-00170, Task Order No. 17, Sest Inc. 


\begin{tabular}{|c|c|c|c|c|c|}
\hline \multicolumn{5}{|c|}{ REPORT DOCUMENTATION PAGE } & $\begin{array}{l}\text { Form Approved } \\
\text { OMB No. 0704-0188 }\end{array}$ \\
\hline \multicolumn{6}{|c|}{$\begin{array}{l}\text { The public reporting burden for this collection of information is estimated to average } 1 \text { hour per response, including the time for reviewing instructions, searching existing data sources, gathering and maintaining the } \\
\text { data needed, and completeting and reviewing the collection of information. Send comments regarding this burden estimate or any other aspect of this collection of information, including suggestions for reducing this } \\
\text { burden, to Department of Defense, Washington Headquarters Services, Directorate for Information Operations and Reports (0704-0188), } 1215 \text { Jefferson Davis Highway, Suite } 1204 \text {, Arlington, VA } 22202-4302 \text {. } \\
\text { Respondents should be aware that notwithstanding any other provision of law, no person shall be subject to any penalty for failing to comply with a collection of information if it does not display a currently valid OMB } \\
\text { control number. } \\
\text { PLEASE DO NOT RETURN YOUR FORM TO THE ABOVE ADDRESS. }\end{array}$} \\
\hline \multicolumn{2}{|c|}{$\begin{array}{l}\text { 1. REPORT DATE (DD-MM-YYYY) } \\
01-09-2010\end{array}$} & \multicolumn{3}{|c|}{$\begin{array}{l}\text { 2. REPORT TYPE } \\
\text { Technical Memorandum }\end{array}$} & 3. DATES COVERED (From - To) \\
\hline \multirow{3}{*}{\multicolumn{5}{|c|}{$\begin{array}{l}\text { 4. TITLE AND SUBTITLE } \\
\text { Evaluating the Acoustic Effect of Over-the-Rotor Foam-Metal Liner Installed on a Low } \\
\text { Speed Fan Using Virtual Rotating Microphone Imaging }\end{array}$}} & 5a. CONTRACT NUMBER \\
\hline & & & & & 5b. GRANT NUMBER \\
\hline & & & & & 5c. PROGRAM ELEMENT NUMBER \\
\hline \multirow{3}{*}{\multicolumn{5}{|c|}{$\begin{array}{l}\text { 6. AUTHOR(S) } \\
\text { Sutliff, Daniel, L.; Dougherty, Robert, P.; Walker, Bruce, E. }\end{array}$}} & 5d. PROJECT NUMBER \\
\hline & & & & & 5e. TASK NUMBER \\
\hline & & & & & $\begin{array}{l}\text { 5f. WORK UNIT NUMBER } \\
\text { WBS 561581.02.08.03.18.03 }\end{array}$ \\
\hline \multicolumn{5}{|c|}{$\begin{array}{l}\text { 7. PERFORMING ORGANIZATION NAME(S) AND ADDRESS(ES) } \\
\text { National Aeronautics and Space Administration } \\
\text { John H. Glenn Research Center at Lewis Field } \\
\text { Cleveland, Ohio 44135-3191 }\end{array}$} & $\begin{array}{l}\text { 8. PERFORMING ORGANIZATION } \\
\text { REPORT NUMBER } \\
\text { E-17431 }\end{array}$ \\
\hline \multirow{2}{*}{\multicolumn{5}{|c|}{$\begin{array}{l}\text { 9. SPONSORING/MONITORING AGENCY NAME(S) AND ADDRESS(ES) } \\
\text { National Aeronautics and Space Administration } \\
\text { Washington, DC 20546-0001 }\end{array}$}} & $\begin{array}{l}\text { 10. SPONSORING/MONITOR'S } \\
\text { ACRONYM(S) } \\
\text { NASA }\end{array}$ \\
\hline & & & & & $\begin{array}{l}\text { 11. SPONSORING/MONITORING } \\
\text { REPORT NUMBER } \\
\text { NASA/TM-2010-216800 }\end{array}$ \\
\hline \multicolumn{6}{|c|}{$\begin{array}{l}\text { 12. DISTRIBUTION/AVAILABILITY STATEMENT } \\
\text { Unclassified-Unlimited } \\
\text { Subject Category: } 71 \\
\text { Available electronically at http://gltrs.grc.nasa.gov } \\
\text { This publication is available from the NASA Center for AeroSpace Information, 443-757-5802 }\end{array}$} \\
\hline \multicolumn{6}{|c|}{ 13. SUPPLEMENTARY NOTES } \\
\hline \multirow{2}{*}{\multicolumn{6}{|c|}{$\begin{array}{l}\text { 14. ABSTRACT } \\
\text { An in-duct beamforming technique for imaging rotating broadband fan sources has been used to evaluate the acoustic characteristics of a } \\
\text { Foam-Metal Liner installed over-the-rotor of a low-speed fan. The NASA Glenn Research Center's Advanced Noise Control Fan was used } \\
\text { as a test bed. A duct wall-mounted phased array consisting of several rings of microphones was employed. The data are mathematically re- } \\
\text { sampled in the fan rotating reference frame and subsequently used in a conventional beamforming technique. The steering vectors for the } \\
\text { beamforming technique are derived from annular duct modes, so that effects of reflections from the duct walls are reduced. } \\
\text { 15. SUBJECT TERMS } \\
\text { Fan noise; Phased array }\end{array}$}} \\
\hline & & & & & \\
\hline \multicolumn{3}{|c|}{ 16. SECURITY CLASSIFICATION OF: } & $\begin{array}{l}\text { 17. LIMITATION OF } \\
\text { ABSTRACT }\end{array}$ & $\begin{array}{l}\text { 18. NUMBER } \\
\text { OF }\end{array}$ & \begin{tabular}{|l|} 
19a. NAME OF RESPONSIBLE PERSON \\
STI Help Desk (email:help@sti.nasa.gov)
\end{tabular} \\
\hline $\begin{array}{l}\text { a. REPORT } \\
\mathrm{U}\end{array}$ & $\begin{array}{l}\text { b. ABSTRACT } \\
\text { U }\end{array}$ & \begin{tabular}{|l|} 
C. THIS \\
PAGE \\
U
\end{tabular} & UU & $\begin{array}{l}\text { PAGES } \\
19\end{array}$ & $\begin{array}{l}\text { 19b. TELEPHONE NUMBER (include area code) } \\
443-757-5802\end{array}$ \\
\hline
\end{tabular}



